\title{
Response of a DIN 18MnCrSiMo6-4 Continuous Cooling Bainitic Steel to Plasma Nitriding with a Nitrogen Rich Gas Composition
}

\author{
Rafael Luciano Dalcin ${ }^{a}$ (D), Leonardo Fonseca Oliveira ${ }^{a}$ (D), Igor Luis Diehl (D), $^{\text {(D) }}$ \\ Vinicius Waechter Dias ${ }^{a}$ (D), Alexandre da Silva Rocha ${ }^{a}$ (D) \\ ${ }^{a}$ Universidade Federal do Rio Grande do Sul - (UFRGS), Porto Alegre, RS, Brasil
}

Received: January 24, 2020; Revised: April 1, 2020; Accepted: April 7, 2020

\begin{abstract}
The use of continuous cooling bainitic steels can provide a more energy efficient manufacturing route. However, for their use in mechanical components like gears, it is necessary to improve their surface properties without impacting the core properties to guarantee reliable mechanical performance. The effect of temperature and time on the plasma nitriding response of a DIN 18MnCrSiMo6-4 steel was investigated. The plasma nitriding was performed for 3,6 and 9 hours, at $400,450,500$ and $550{ }^{\circ} \mathrm{C}$, using a gas mixture composed of 76 vol.\% nitrogen and 24 vol.\% hydrogen. Samples were characterized before and after plasma nitriding concerning the microstructure, hardness and microhardness, fracture toughness, phase composition and residual stress states. Based on the results presented, layer growth constants $(k)$ for different temperatures was determined. Moreover, it could be found that $500{ }^{\circ} \mathrm{C}$ gave the best results investigated here, as higher temperature took to core and surface hardness decrease. The nitrided samples with thicker compound layers presented a fracture behavior dominated by the formation of Palmqvist cracks. X-ray phase analysis indicated the formation of biphasic compound layer on the surface of all nitrided samples. The diffusion zone presented compressive residual stresses with highest values near the surface.
\end{abstract}

Keywords: DIN 18MnCrSiMo6-4 Steel, Plasma Nitriding, Layer Growth Constant, Fracture Toughness, Residual Stress Analysis.

\section{Introduction}

Automotive products need to accomplish with customer demands and governmental requirements. This challenge is associated to the development of new materials aiming at vehicle mass reduction. By the way, the steel industry has been developing new steels with unique metallurgical properties (such as good formability and final high strength) and processing methods that enable to meet requirements for safety, efficiency, low gas emissions, manufacturability, durability and quality at relatively low $\operatorname{cost} \mathrm{t}^{1-3}$. Recent developments of direct heat-treated steels for high strength forgings have led to some new steel grades with excellent service properties ${ }^{4-7}$.

Precipitation hardened ferritic-pearlitic steels and bainitic steels can replace quenched and tempered steels ${ }^{7}$. Unlikely the quenched and tempered steels, requiring subsequent heat treatment to obtain suitable properties for their applications, the continuous cooling bainitic steels already exhibit high levels of strength and toughness after hot rolling or forging with a direct controlled cooling, presenting consequently the potential to shorten the manufacturing cycle and to reduce costs ${ }^{4,8,9}$.

Therefore, the new generation of continuous cooling bainitic steels can reduce energy expenses during manufacturing, however, it is necessary to improve their surface properties without impacting the core properties. The plasma nitriding process, as it allows the use of relatively low temperatures,

*e-mail: rldalcin@gmail.com represents an alternative to conventional surface hardening treatments ${ }^{10-12}$. Since nitriding does not involve heating in the austenitic phase field (as occurs in induction hardening and carburizing) and rapid cooling to form martensite, nitriding can be performed with minimal distortion and excellent dimensional control ${ }^{13,14}$. Besides that, the use of plasma in the nitriding process is able to reduce temperature treatments in relation to gas nitriding, increase treatment efficiency and reach a better control of properties ${ }^{15-17}$. This work aims at evaluating the effects of different combinations of time and temperature of plasma nitriding treatments on DIN 18MnCrSiMo6-4 bainitic steel, concerning the surface modification and the stability of the core microstructure due to the exposure to typical plasma nitriding temperatures.

\section{Materials and Methods}

\subsection{Material under investigation}

The material used for this study was a DIN 18MnCrSiMo6-4 continuous cooling bainitic steel. This still was controlled hot rolled and cooled with an adequate cooling rate in air for the development of a granular bainitic microstructure, providing a good compromise between yield strength, hardness and toughness ${ }^{6,7,18}$. The material chemical composition is given in Table 1. The amounts of $\mathrm{Si}, \mathrm{Mn}$ and $\mathrm{Cr}$ allow the bainitic transformation to occur in higher percentage during continuous cooling ${ }^{4}$. 
Figure 1 reveals the material's microstructure by optical microscopy. The microstructure is composed of pro-eutectoid ferrite and granular bainite. Granular bainite is formed of martensite/austenite (M/A) constituents and retained austenite ${ }^{4,19-21}$. The material's mechanical properties (average values) are: $825 \mathrm{MPa}$ yield strength, $1017 \mathrm{MPa}$ tensile strength, $17 \%$ elongation and $330 \mathrm{HV}_{0.1}$ hardness.

\subsection{Samples preparation and plasma nitriding}

For plasma nitriding, samples were disks with $10 \mathrm{~mm}$ of height and $43.2 \mathrm{~mm}$ of diameter manufactured from cylindrical bars of a continuous cooling bainitic steel DIN $18 \mathrm{MnCrSiMo6}-4$. Prior to the surface treatments, samples flat faces were ground with silicon carbide grinding paper in a sequence with increasing mesh (\#100,\#220,\#320,\#400, $\# 600, \# 1200$ ) and then polished with diamond paste with an abrasive size of $3 \mu \mathrm{m}$ in order to obtain low roughness, almost no plastic deformation and consequently low initial residual stresses in the surface.

Plasma nitriding was carried out in a plasma nitriding furnace equipped with a DC power supply which was developed in the Metallurgical Department of Federal University of Rio Grande do Sul (UFRGS). The samples were degreased and cleaned with acetone in an ultrasonic bath before being placed into the furnace. After cleaning, the specimens were heated and sputter cleaned in plasma. The nitriding temperature was reached in an atmosphere containing argon under a $300 \mathrm{~Pa}$ pressure. For the nitriding process using a gas mixture composed of 76 vol.\% nitrogen $\left(\mathrm{N}_{2}\right)$ and 24 vol.\% hydrogen $\left(\mathrm{H}_{2}\right)$, the parameters are shown in Table 2.

\subsection{Properties evaluation after plasma nitriding}

\subsubsection{Microstructural Analysis and Compound Layer Thickness Measurements}

For the microstructural analysis of the nitrided layers, samples were carefully cut in a precision diamond blade cutting machine and mounted in bakelite using a metallic

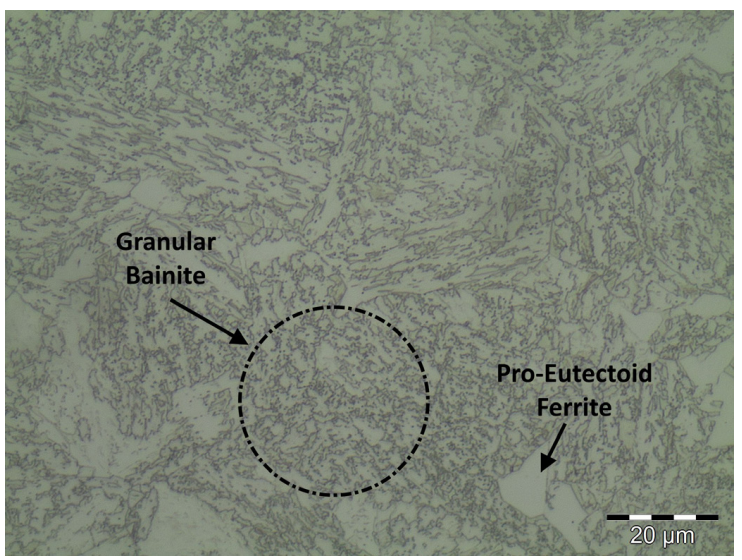

Fig. 1. Optical micrograph of a DIN 18MnCrSiMo6-4 continuous cooling bainitic steel. support on the nitrided surface to promote edge retention. After mounting, the cross-sections were ground with silicon grinding paper in a sequence with increasing mesh (\#100,\#220,\#320,\#400, \#600,\#1200) and polished with a diamond paste of $3 \mu \mathrm{m}$ grain size. A Nital 3\% solution was used to etch the samples revealing the microstructure of the nitrided layers. The cross-sectional microstructural images were obtained in an OLYMPUS GX-51 optical microscope. The compound layer thickness was measured using the software IMAGE $J^{T M}$.

\subsubsection{Surface/Core hardness and case depth measurements}

Rockwell $\mathrm{C}$ hardness tests were carried out using a PRECISION MRS EXP (Universal Hardness tester) to verify the core hardness of the samples after the plasma nitriding treatments ${ }^{22}$. After plasma nitriding, surface Vickers microhardness measurements of the face of the nitrided sample and Vickers microhardness profiles of the cross-sections were obtained with an INSIZE ISH-TDV 1000 micro hardness tester. Five microhardness profiles were constructed by Vickers microhardness testing, using a load of $100 \mathrm{gf}$ with an application time of $10 \mathrm{~s}^{23}$. The determination of the nitrided layer depth was carried out based on the microhardness profiles and following the recommendations established in DIN $50190^{24}$. Therefore, the end of the nitride layer (compound layer + diffusion zone) was conventionally determined by the position where hardness measurements are $50 \mathrm{HV}$ above core hardness.

\subsubsection{Fracture Toughness Evaluation from Vickers Indentation}

In order to determine the fracture toughness of the nitrided layer, the analysis model proposed by Nolan et al. ${ }^{25}$ was applied. This method was chosen because the Vickers pyramid indenter has edges at $90^{\circ}$ to induce the formation of measurable Palmqvist cracks. This method rely on the shape

Table 2. Parameters used for plasma nitriding of samples using a gas composition of 76 vol. $\%$ nitrogen $\left(\mathrm{N}_{2}\right)$ and 24 vol. $\%$ hydrogen $\left(\mathrm{H}_{2}\right)$.

\begin{tabular}{cccc}
\hline $\begin{array}{c}\text { Temperature } \\
\left({ }^{\circ} \mathrm{C}\right)\end{array}$ & $\begin{array}{c}\text { Nitriding time } \\
(\mathrm{h})\end{array}$ & $\begin{array}{c}\text { Power, rms } \\
(\mathrm{kVA})\end{array}$ & $\begin{array}{c}\text { Chamber } \\
\text { pressure }(\mathrm{Pa})\end{array}$ \\
\hline 550 & 3 & 1.5 & 300 \\
\hline 550 & 6 & 1.5 & 300 \\
\hline 550 & 9 & 1.6 & 300 \\
\hline 500 & 3 & 1.0 & 300 \\
\hline 500 & 6 & 1.1 & 300 \\
\hline 500 & 9 & 1.1 & 300 \\
\hline 450 & 3 & 1.0 & 300 \\
\hline 450 & 6 & 1.0 & 300 \\
\hline 450 & 9 & 1.0 & 300 \\
\hline 400 & 3 & 0.9 & 300 \\
\hline 400 & 6 & 0.9 & 300 \\
\hline 400 & 9 & 0.9 & 300 \\
\hline
\end{tabular}

Table 1. Chemical composition of the DIN 18MnCrSiMo6-4 (wt.-\%).

\begin{tabular}{cccccccccccc}
\hline $\mathrm{C}$ & $\mathrm{Si}$ & $\mathrm{Mn}$ & $\mathrm{P}$ & $\mathrm{S}$ & $\mathrm{Cr}$ & $\mathrm{Mo}$ & $\mathrm{Ni}$ & $\mathrm{Fe}$ \\
\hline 0.19 & 1.16 & 1.35 & 0.01 & 0.01 & 1.14 & 0.26 & 0.06 & 0.01 & Balance \\
\hline
\end{tabular}


of the cracks developed by the hardness indenter. Fracture toughness $\left(\mathrm{K}_{\mathrm{IC}}\right)$ is estimated by visualizing and measuring cracks formed around hardness test indentations. Nitrided samples were slightly polished using $3 \mu \mathrm{m}$ diamond paste for 20 seconds, then in a Vickers hardness test indentations on samples nitride faces were carried out with increasing loads $(1,5,10,20,30$ and $50 \mathrm{kgf})$. The minimum load necessary to generate an observable Palmqvist crack on the surface was recorded for each tested sample.

The crack length was measured under an optical microscope, and the average values of Vickers indentation diagonals length and cracks length were used to calculate the $\mathrm{K}_{\mathrm{IC}}$, according to the simplified relationship developed by Shetty et al. ${ }^{26}$, as given in Equation 1 . The relation is valid for valid for the Palmqvist crack mode. $l$ is the mean length of the crack, $a$ is the mean length of the indentation diagonals and $P$ is the applied load on the test.

$$
K_{I C}=0.0319\left(\frac{P}{a \sqrt{l}}\right)
$$

It has been suggested that the Equation will give an estimate of the crack arrest fracture toughness $\left(\mathrm{K}_{\mathrm{IC}}\right)$. According to the Palmqvist theory, fracture toughness $\left(\mathrm{K}_{\mathrm{IC}}\right)$ should be independent of the applied load. The most valid measure of $\mathrm{K}_{\mathrm{IC}}$ for the thin coating can therefore be obtained by extrapolating the $\mathrm{K}_{\mathrm{IC}}$ versus $\mathrm{P}$ data to $\mathrm{P}=0$, where the intrinsic fracture toughness of the coating, denoted by $\mathrm{K}_{\mathrm{IC} 0}$, can be derived ${ }^{25}$.

\subsubsection{Phase and residual stress analysis by X-ray diffraction}

Phase and Residual Stress X-ray diffraction was carried out using a GE SEIFERT CHARON XRD M-RESEARCH EDITION Diffractometer equipped with a METEOR $1 D$ fast line position sensitive detector. Phase analysis was performed on samples surface in the Bragg-Brentano geometry condition $(\theta-2 \theta)$ with $\mathrm{Cr}-\mathrm{K} \alpha(\lambda=2.2897 \AA)$ radiation. Diffraction lines were recorded in the range of $2 \theta$ from $50^{\circ}$ to $166^{\circ}$, with $0.01^{\circ}$ spacing and a scan time of $200 \mathrm{~s}$ for each step. Residual stresses were determined at three different positions on the samples faces by using a $\psi$-diffractometer with $\mathrm{Cr}-\mathrm{K \alpha}$ radiation. For strain determination the $\{211\}$ diffraction lines of $\alpha$-iron were recorded at $15 \psi$ inclinations in the range of $-60^{\circ}$ to $+60^{\circ}$. The $\sin ^{2} \psi$ method with macroscopic elastic constants of steel, $E=210.000 \mathrm{MPa}$ and $v=0.28$, was used for residual stress calculations. The penetration depth of

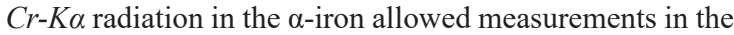
diffusion zone, even with a small layer at the surface.

In order to obtain residual stress profiles of the samples near surface, before each measurement a depth layer removal was carried out by electrolytic etching. During the layer removal process, the samples were dipped into a solution containing $24.19 \%$ distilled water mixed with $33.87 \%$ sulfuric acid $\left(\mathrm{H}_{2} \mathrm{SO}_{4}\right)$ and $41.94 \%$ phosphoric acid $\left(\mathrm{H}_{3} \mathrm{PO}_{4}\right)$, a magnetic stirrer to mix the solution was used during all process. Sample was connected to the anode and the stainless steel basket, which contained the electrolytic solution, was connected to the cathode. A ddp of $10 \mathrm{~V}$ was applied giving a current of about $10 \mathrm{~A}$ during the removal process. Sample thickness was measured before and after a pre-set attack time using a micrometer. The estimated depth measurement error was $\pm 1 \mu \mathrm{m}$. About eight removals with successive measurements were carried out for each sample.

\section{Results and Discussion}

\subsection{Modification of Surface/Core properties after plasma nitriding}

As a representative result of the plasma nitriding treatments using the gas with $76 \mathrm{vol} . \% \mathrm{~N}_{2}$, a cross-sectional microstructure of a sample treated at $450{ }^{\circ} \mathrm{C}$ for 6 hours is presented in Figure 2. The treatments developed the formation of a compound layer in the outermost superficial part of the specimens, followed by the diffusion layer below. The thin white portion on top distinguishes the compound layer. For nitrided samples at the lowest temperature $\left(400{ }^{\circ} \mathrm{C}\right)$ the nitrided layer is predominantly composed of the diffusion zone with a very thin compound layer (see Table 3 ). Under conditions where samples were nitrided at temperatures higher than $400{ }^{\circ} \mathrm{C}$, effective compound layer appears in the metallography. Precipitation of chromium nitride also occurred and depleted the free chromium from the substrate. According to Li et al. ${ }^{15}$ this leads to the formation of "dark" phases and/or a completely "dark layer" in the nitrided surface.

Table 3 summarizes the results regarding the optical microscopy cross-sectional analysis of the nitrided samples. The compound layer thickness increases with the temperature and time. A similar response is observed for the total case

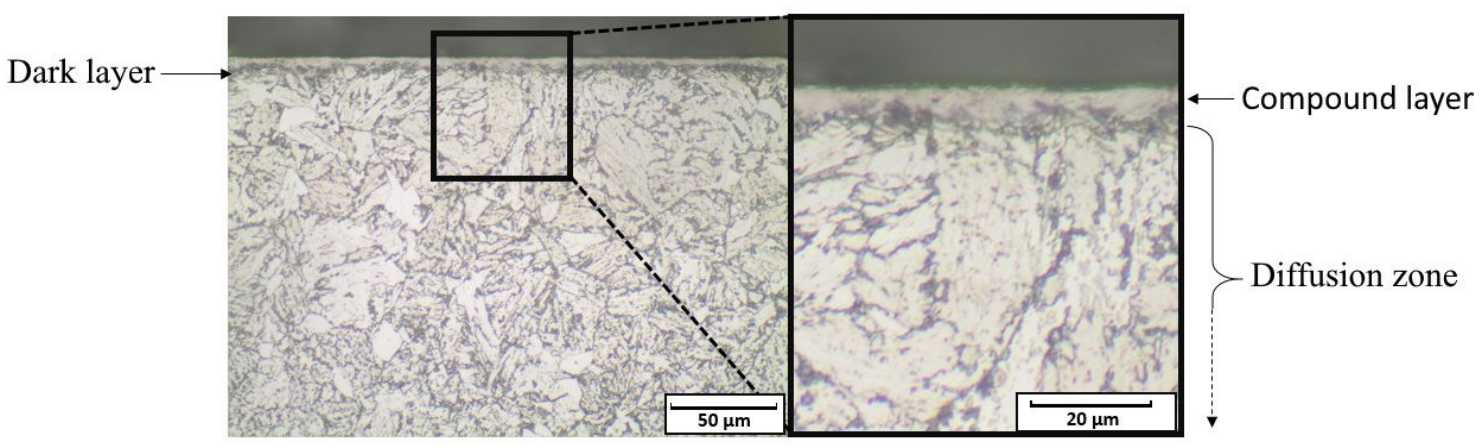

Fig. 2. Optical microstructure of cross-section of plasma nitrided sample at $450{ }^{\circ} \mathrm{C}$ for $6 \mathrm{~h}$. 
depths. The case depth $(C D)$, Equation 2, is directly proportional to the square root of the processing time by the layer growth constant $(k)$ which includes the variables temperature, chemical composition of the steel and concentration gradient of a given hardening species. In terms of temperature, the layer growth constant increases exponentially as a function of absolute temperature. This allows diffusional processes to be considered thermally activated ${ }^{27}$.

Sun; Bell ${ }^{17}$ showed that, under constant temperature conditions, there is a potential limit for the formation of the compound layer that depends on the nitrogen fraction in the gas mixture and the nitriding time. Below this potential limit, only the formation of the diffusion zone occurs. That is clear from the present results (Table 3 ) that nitriding was carried out above this limit condition, and the limit temperature would be under $400^{\circ} \mathrm{C}$ for the nitrogen rich gas composition used, as the presence of a compound layer was always detected.

$$
C D=k \cdot \sqrt{\text { time }}
$$

When nitriding at $550{ }^{\circ} \mathrm{C}$, the total layer depth is the highest for all nitriding times. The surface measured hardness decreases, especially for longer treatments of 6 and 9 hours. The core hardness is also decreased in the samples treated at $550{ }^{\circ} \mathrm{C}$ which is not observed for the other treatment temperatures. For this temperature, there is a competition between the hardening effect of nitriding and the hardness decrease due to the over-tempering of the benefited matrix, so that the maximum hardening potential is not reached. Another explanation is that higher nitriding temperature leads to the intensification of defects formed in the nitrided layer, such as pores and cracks, where the hardness of the layer and compounds is compromised and therefore the hardness value decreases ${ }^{28}$. On the other hand, the lower hardness for the nitrided sample at $400{ }^{\circ} \mathrm{C}$ is more related to a measuring effect. The layer thickness is very small, so that the measured hardness will have higher contribution of the deeper layers with relatively lower hardness, considering a higher hardness gradient in the samples.

\subsection{Fracture toughness}

Regarding an expected decrease in toughness as surface hardness increases, fracture toughness tests were performed based on the method presented by Nolan et al. ${ }^{25}$, to induce the formation of measurable Palmqvist cracks (an example is presented in Figure 3a). Due to reasons previously reported and the fact that this fracture toughness test is not yet fully established for nitrided layers, the load failure criterion was adopted as the load at which it was possible to verify by optical microscopy the beginning of cracking around the indentation. An example concentric cracking is shown in Figure 3b. For plasma nitriding temperatures of 400 and $450{ }^{\circ} \mathrm{C}$, regarding the indentation impressions and the fracture mode observed, there were few cases of indentations producing Palmqvist cracks.

The predominant mode of cracking for these cases was concentric rings, becoming more evident and more extensive with higher loads. Palmqvist cracks are clearly developed for nitrided samples at temperatures of 500 and $550{ }^{\circ} \mathrm{C}$, however, the appearance of concentric cracking also became apparent, becoming more significant with increasing load. The reason for this is not immediately apparent, although probably related to the increased thickness of the compound layer. As the compound layer thickness decreases and/or the indentation depth increases (also by increasing load), the indentation effects are not restricted to the compound layer, and plastic deformation in the diffusion zone will occur, since the diffusion zone is much more ductile than the compound layer. Then in these cases, there is a load bearing capacity failure for the compound layer, appearing the concentric cracks around the indentations. On the other hand, for thicker compound layers and/or lower loads the indentation effects are restricted to the compound layer, without plastic deformation in the diffusion zone, which leads to the typical Palmqvist.

The calculated $\mathrm{K}_{\mathrm{IC}}$ for each condition is shown in Figures $4 \mathrm{a}, \mathrm{b}$. Where a condition showed no Palmqvist cracking, a value of zero is presented for $\mathrm{K}_{\mathrm{IC}}$. A valid estimate of $\mathrm{K}_{\mathrm{IC} 0}$ for plasma nitriding temperatures of 400 and $450{ }^{\circ} \mathrm{C}$ is not possible, since there are so few cases where Palmqvist cracking is evident. In the case of nitrided samples at temperatures of 500 and $550{ }^{\circ} \mathrm{C}$, it may be possible to extrapolate a value for $\mathrm{K}_{\mathrm{IC} 0}$ in order of 5.9-7.7 MN/m $/ \mathrm{m}^{3 / 2}$ particularly with the plasma nitrided samples at temperature of $550^{\circ} \mathrm{C}$ (see Figure $4 \mathrm{~b}$ ). However, in the case of plasma

Table 3. Modification of surface/core properties after plasma nitriding*.

\begin{tabular}{|c|c|c|c|c|c|}
\hline Nitriding parameters & $\begin{array}{c}\text { Compound layer } \\
\text { thickness }(\mu \mathrm{m})\end{array}$ & Case depth $(\mu \mathrm{m})$ & $\begin{array}{l}\text { Layer growth } \\
\text { constant }\end{array}$ & $\begin{array}{c}\text { Core hardness } \\
\text { (HRC) }\end{array}$ & $\begin{array}{c}\text { Surface hardness } \\
\left(\mathrm{HV}_{0.1}\right)\end{array}$ \\
\hline $550^{\circ} \mathrm{C}-3 \mathrm{~h}$ & $7.9 \pm 0.3$ & $253.4 \pm 23.5$ & \multirow{3}{*}{115.5} & $31.9 \pm 0.9$ & $1195.0 \pm 45.0$ \\
\hline $550^{\circ} \mathrm{C}-6 \mathrm{~h}$ & $9.6 \pm 0.3$ & $308.6 \pm 24.4$ & & $30.7 \pm 0.8$ & $1088.9 \pm 46.2$ \\
\hline $550^{\circ} \mathrm{C}-9 \mathrm{~h}$ & $11.5 \pm 0.2$ & $335.6 \pm 15.6$ & & $30.5 \pm 0.7$ & $1028.8 \pm 50.2$ \\
\hline $500{ }^{\circ} \mathrm{C}-3 \mathrm{~h}$ & $4.3 \pm 0.2$ & $139.2 \pm 30.3$ & \multirow{3}{*}{80.5} & $34.0 \pm 1.1$ & $1246.2 \pm 95.5$ \\
\hline $500^{\circ} \mathrm{C}-6 \mathrm{~h}$ & $6.7 \pm 0.3$ & $192.4 \pm 24.9$ & & $33.5 \pm 0.7$ & $1294.8 \pm 107.8$ \\
\hline $500^{\circ} \mathrm{C}-9 \mathrm{~h}$ & $8.2 \pm 0.2$ & $245.4 \pm 40.3$ & & $33.2 \pm 0.8$ & $1079.2 \pm 86.7$ \\
\hline $450^{\circ} \mathrm{C}-3 \mathrm{~h}$ & $2.6 \pm 0.3$ & $97.6 \pm 20.5$ & \multirow{3}{*}{55.4} & $34.4 \pm 1.2$ & $1253.5 \pm 55.9$ \\
\hline $450^{\circ} \mathrm{C}-6 \mathrm{~h}$ & $3.9 \pm 0.2$ & $131.1 \pm 24.5$ & & $34.5 \pm 1.0$ & $1105.3 \pm 89.9$ \\
\hline $450^{\circ} \mathrm{C}-9 \mathrm{~h}$ & $4.8 \pm 0.4$ & $169.3 \pm 40.4$ & & $34.5 \pm 0.8$ & $1101.5 \pm 56.2$ \\
\hline $400^{\circ} \mathrm{C}-3 \mathrm{~h}$ & $0.6 \pm 0.2$ & $66.8 \pm 19.9$ & \multirow{3}{*}{41.3} & $34.0 \pm 0.8$ & $1060.4 \pm 38.6$ \\
\hline $400{ }^{\circ} \mathrm{C}-6 \mathrm{~h}$ & $1.5 \pm 0.2$ & $98.5 \pm 11.7$ & & $34.1 \pm 1.2$ & $1050.9 \pm 28.2$ \\
\hline $400^{\circ} \mathrm{C}-9 \mathrm{~h}$ & $2.7 \pm 0.3$ & $125.1 \pm 21.5$ & & $33.9 \pm 0.9$ & $1095.5 \pm 94.8$ \\
\hline
\end{tabular}

${ }^{*}$ All samples were plasma nitrided with gas mixture of 76 vol. $\%$ nitrogen and 24 vol.\% hydrogen. 


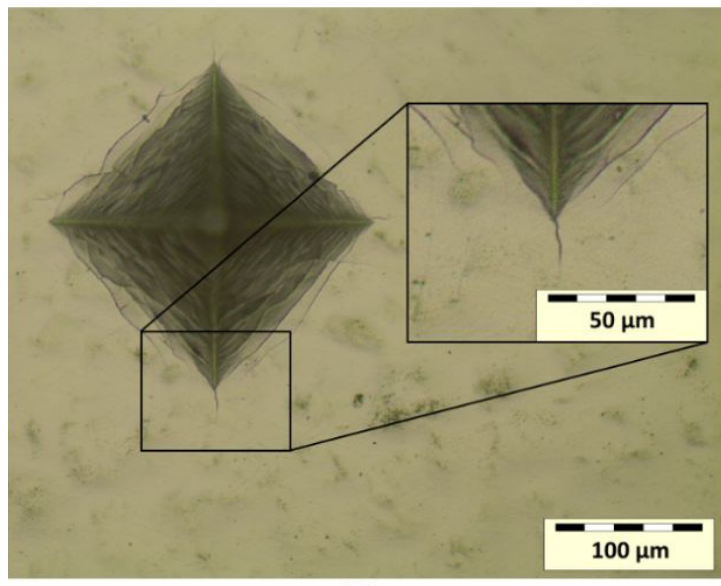

(a)

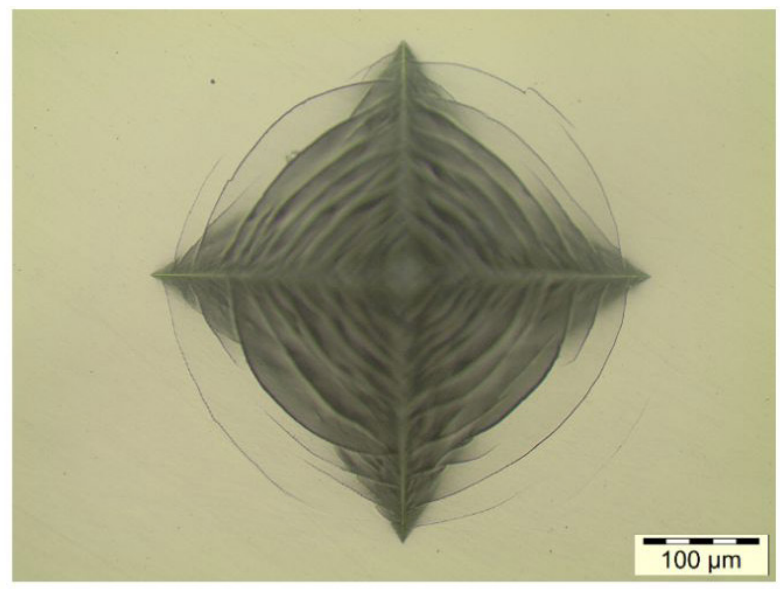

(b)

Fig. 3. Representative images of the fracture toughness tests: (a) Palmqvist cracks of plasma nitrided sample at $500{ }^{\circ} \mathrm{C}$ for $6 \mathrm{~h}$. Indentation load of $20 \mathrm{kgf}$; (b) concentric ring cracks of plasma nitrided sample at $450{ }^{\circ} \mathrm{C}$ for $9 \mathrm{~h}$. Indentation load of $50 \mathrm{kgf}$.

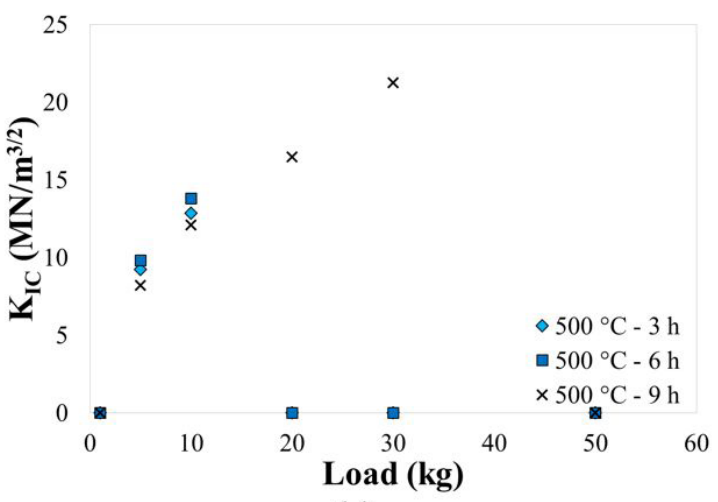

(a)

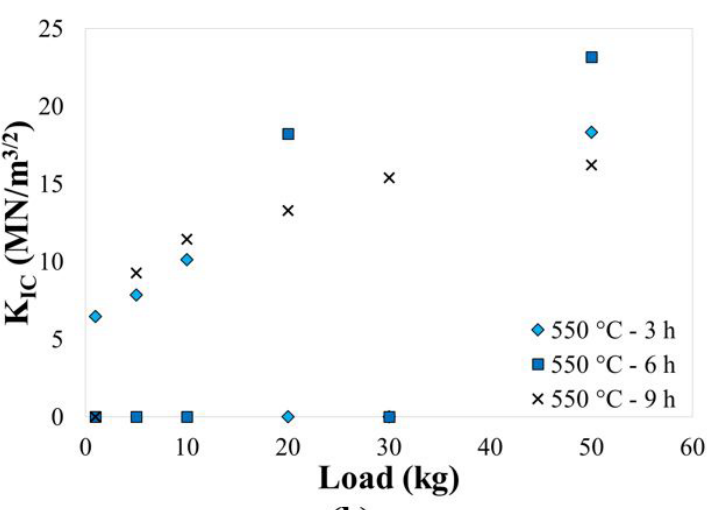

(b)

Fig. 4. $\mathrm{K}_{\mathrm{IC}}$ calculated for the plasma nitrided samples at temperature of (a) $500{ }^{\circ} \mathrm{C}$ and (b) $550{ }^{\circ} \mathrm{C}$.

nitrided samples at $500{ }^{\circ} \mathrm{C}$, there is a clear trend of fracture toughness data, which enables extrapolation to a $\mathrm{K}_{\mathrm{IC} 0}$ value of $\sim 5.2-5.8 \mathrm{MN} / \mathrm{m}^{3 / 2}$ (see Figure $4 \mathrm{a}$ ).

Plasma nitriding leads to an increase in hardness on the surface, for the reason it also ends up creating a less ductile region more prone to brittle fracture. The mechanical properties of the diffusion zone influence the fracture properties of the compound layer, since the diffusion zone provides support for the surface compound layer. In general, increased nitriding time seems to result in increased fracture toughness for samples where there is consistent thickness of the compound layer. This would also support the proposition that a harder substrate actually results in an increase in fracture toughness measurement through improved mechanical support (load bearing capacity) of the compound layer by the diffusion zone. Although the average concentric rings indicate detachment of the compound layer due to the crack initiation below this. However, cracks originated on the compound layer can also be harmful, especially in components that support high loads and alternate loading, as they can represent the onset of a fatigue failure, for example. Attention must be paid to the fact that the transition from Palmqvist cracks to medium concentric cracking may determine the onset of cracks in the diffusion zone and/or in material's core.

\subsection{Phase and residual stress analysis}

Figures 5a-d shows the diffractograms of plasma-nitrided samples and a non-nitrided sample (used as a reference). The sample of the non-nitrided steel is basically characterized by the presence of the $\alpha$-Iron peaks in positions $68.8^{\circ} ; 106.1^{\circ}$ and $156.3^{\circ}$, however, it is not possible to distinguish clearly whether it is ferrite, bainite or martensite. According to Gong et al. ${ }^{29}$, the broadening of the peak, indicates the presence of bainite/martensite.

The $\alpha$ phase peaks of the nitrided samples are slightly shifted to the region of lower $2 \theta$ angle with respect to the sample without nitriding. It is also important to point out that this is an information coming from the diffusion layer, as the compound layer is composed by (carbo)nitrides only. This indicates a lattice spacing, referring to the measured $\psi=0^{\circ}$ angle, smaller than that measured in the non-nitrided sample, according to Bragg's Law, indicating compressive residual stresses in the direction parallel to surface. As the nitride layer suffers an expansion by the formation of nitrides and the nitrogen in solid solution, the diffusion layer 


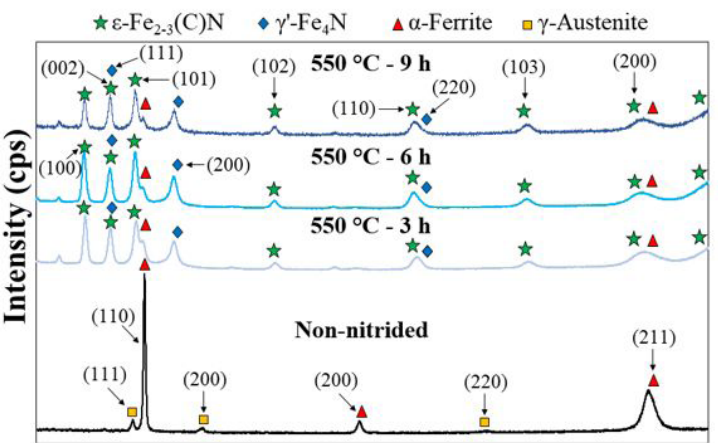

$\begin{array}{llllllllllll}50 & 60 & 70 & 80 & 90 & 100 & 110 & 120 & 130 & 140 & 150 & 160\end{array}$ Diffraction angle (20)

(a)

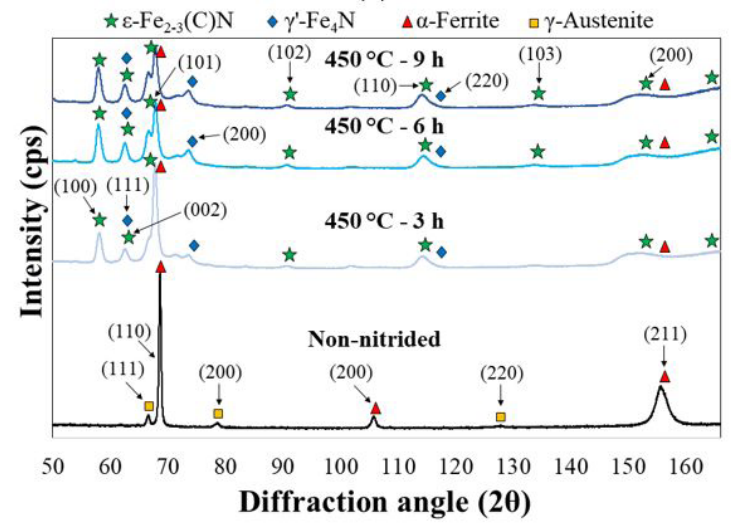

(c)

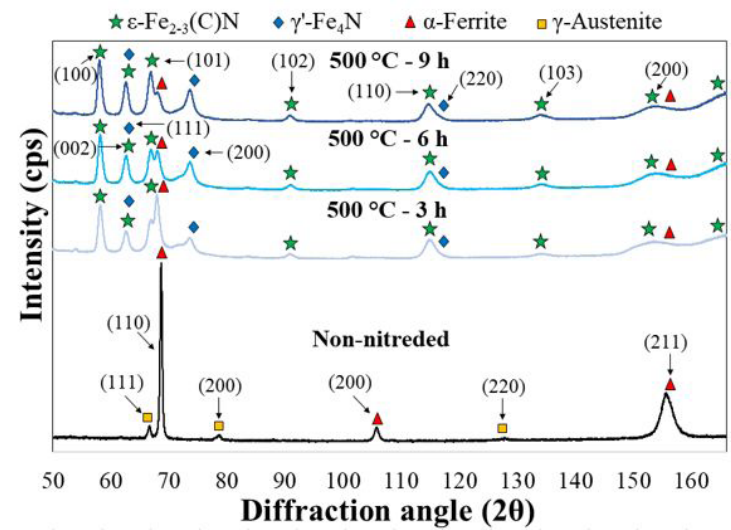

(b)

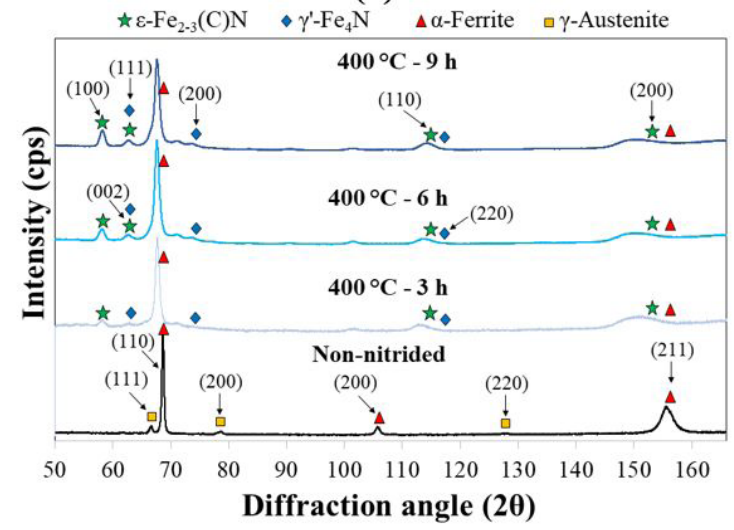

(d)

Fig. 5. X-ray diffractograms of non-nitrided sample and plasma nitrided samples at (a) $550{ }^{\circ} \mathrm{C}$, (b) $500{ }^{\circ} \mathrm{C}$, (c) $450{ }^{\circ} \mathrm{C}$ and (d) $400{ }^{\circ} \mathrm{C}$.

will develop a residual stress gradient with the outer most surface presenting higher compression levels in the nitrided layer. Compressive residual stresses in the diffusion zone is a well-known result of nitride steels ${ }^{30-33}$. The increase in the level of compressive residual stresses on the surface of a mechanical component can improve fatigue resistance.

All the nitrided samples showed diffraction peaks that indicate formation of the compound layer. In the diffraction patterns, the $\varepsilon-\mathrm{Fe}_{2-3}(\mathrm{C}) \mathrm{N}$ is detected as the main phase, for the diffraction in the positions: $58.2^{\circ} ; 62.9^{\circ} ; 67.0^{\circ} ; 91.0^{\circ} ; 114.8^{\circ}$; $134.3^{\circ} ; 153.2^{\circ}$ and $164.5^{\circ}$, and there is also evidence for the formation of the $\gamma^{\prime}-\mathrm{Fe}_{4} \mathrm{~N}$ nitride phase by the peaks at the positions: $63.1^{\circ} ; 74.3^{\circ}$ and $117.4^{\circ}$. The intensity of the peaks of the $\alpha$-iron decreases with the increase of the compound's layer thickness, while the $\varepsilon-\mathrm{Fe}_{2-3}(\mathrm{C}) \mathrm{N}$ and $\gamma^{\prime}-\mathrm{Fe}_{4} \mathrm{~N}$ phase peaks intensity increase. This happens due to the absorption of the radiation by the most superficial portions of the material and, therefore, the diffraction intensity weakens. The peaks intensity related to the $\gamma^{\prime}-\mathrm{Fe}_{4} \mathrm{~N}$ nitride phase increase with the treatment temperature due to the increased thickness of the $\gamma$ ' $-\mathrm{Fe}_{4} \mathrm{~N}$ nitride layer. On the other hand, as the $2 \theta$ angle decreases, the radiation penetration depth also decreases, so the peaks of the $\varepsilon-\mathrm{Fe}_{2-3}(\mathrm{C}) \mathrm{N}$ phase are easily identified with smaller $2 \theta$ angles. For larger angles, the $\varepsilon-\mathrm{Fe}_{2-3}(\mathrm{C})$ $\mathrm{N}$ phase diffraction peaks are not observed, especially in treatments at $400{ }^{\circ} \mathrm{C}$, because the compound layer is very thin in these cases. In general, all nitrided samples showed a major presence of $\varepsilon-\mathrm{Fe}_{2-3}(\mathrm{C}) \mathrm{N}$ nitrides in the compound layer and, in a smaller quantity, the $\gamma^{\prime}-\mathrm{Fe}_{4} \mathrm{~N}$ nitride phase.

Figures 6a-c show residual stress depth profiles in the diffusion zone for the different surface treatments. Compressive residual stresses found in the diffusion zone are the result of structural misfits caused by the precipitation of alloy nitrides and carbonitrides in the iron matrix ${ }^{30,34}$. For all nitriding treatment parameters, residual stresses were found to be compressive in the diffusion zone. Compressive residual stresses decrease with depth before approaching tensile values at the case/core microstructure transition, as typically reported in different articles ${ }^{10,30}$. Plasma nitrided samples at lower temperatures (400 and $450{ }^{\circ} \mathrm{C}$ ) exhibit the highest compressive surface residual stresses, when compared to plasma nitrided samples at higher temperatures $\left(500\right.$ and $\left.550^{\circ} \mathrm{C}\right)$. With the increase in nitriding temperature from 400 to $550^{\circ} \mathrm{C}$, as the diffusion zone depth increases, samples exhibit lower compressive surface residual stresses, but present at higher depths.

With the increase of nitriding time, the nitriding temperature of $500^{\circ} \mathrm{C}$ showed a good combination between surface value of residual stresses and depth distribution, since at this temperature higher than $900 \mathrm{MPa}$ in compression were found for all nitriding times. Although the nitriding temperature of $450{ }^{\circ} \mathrm{C}$ kept even higher surface compressive residual stresses (above $1200 \mathrm{MPa}$ ) for all nitriding times, the layer growth is too slow, leading to very long treatment times to reach shallow layers. The best combination, of course will depend on the application. As 


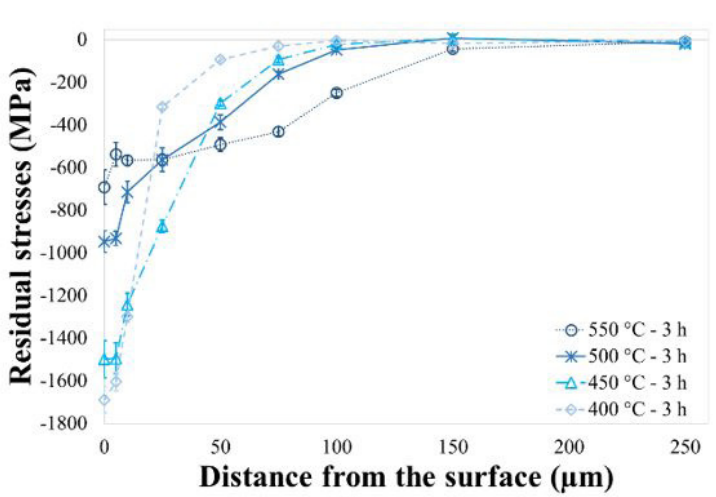

(a)

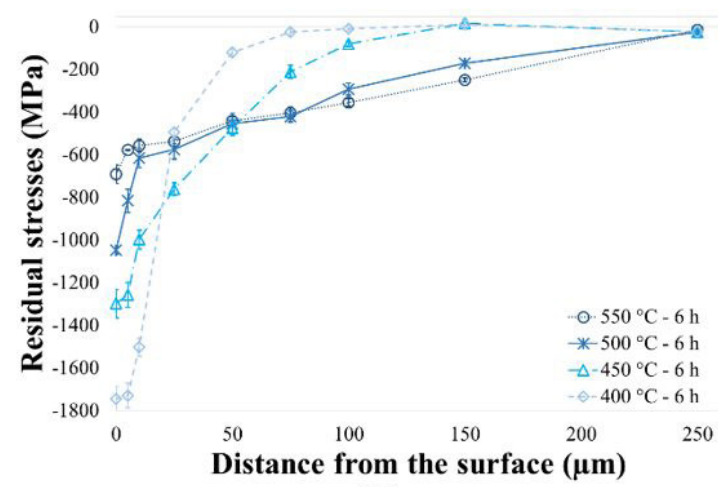

(b)

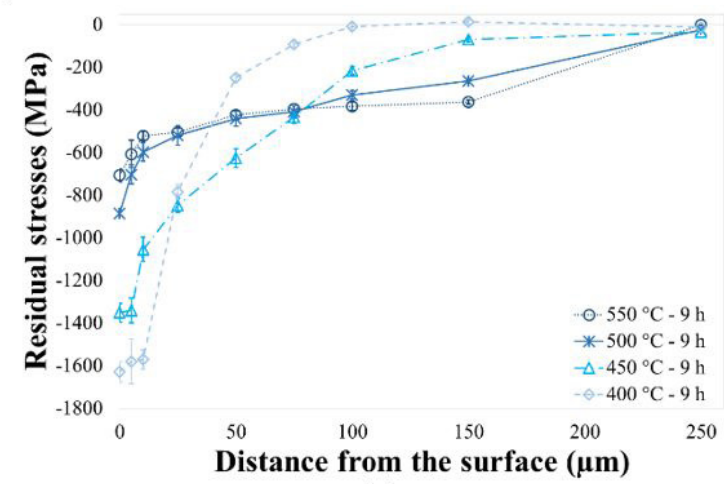

(c)

Fig. 6. Residual stress depth profiles for plasma nitrided samples for (a) $3 \mathrm{~h}$, (b) $6 \mathrm{~h}$ and (c) $9 \mathrm{~h}$.

for example in nitriding of gears, the analysis must take into account the gear tooth flank hertezian stresses and gear tooth root bending stresses. But normally, the case depth should be at least $0.3 \mathrm{~mm}$, and therefore $500{ }^{\circ} \mathrm{C}$ is the best choice to avoid to longer nitriding times. Besides that, too high compressive residual stresses in the interface between diffusion zone and compound layer can lead to earlier surface spalling.

\subsection{Final discussion}

Time and temperature can influence not only the thickness of the compound layer, but also its composition ${ }^{35}$. The X-ray analysis, Figures 5a-d, showed formation of $\varepsilon-\mathrm{Fe}_{2-3}(\mathrm{C}) \mathrm{N}$ and $\gamma^{\prime}-\mathrm{Fe}_{4} \mathrm{~N}$ dual phase compound layer for surface at all treatment conditions using $76 \mathrm{vol} . \%$ nitrogen gas composition.

It might normally be expected that the $\varepsilon-\mathrm{Fe}_{2-3}(\mathrm{C})$ $\mathrm{N}$ containing compound layer would be harder than the $\gamma^{\prime}-\mathrm{Fe}_{4} \mathrm{~N}$ layer on the plasma nitrided samples. However, it was shown in the work of Nolan et al. ${ }^{25}$ proposed that the hardness lowering observed may be a result of very fine closed porosity apparent in the mixed phase compound layer. This porosity, and the fact that the structure is multiphase, may lead to lower fracture toughness values. It is also likely that the mechanical properties of the diffusion layer will influence the fracture properties of the surface layers, since the diffusion layer provides mechanical support for the surface layers ${ }^{25}$. For example, the Palmqvist cracking appears to become more consistent with increasing processing temperature and time for the samples. The reason for this is not immediately apparent, though it is most likely related to the increased thickness of the compound layer and subsequent enhancement of the brittle fracture behavior of the surface.

The compilation of compound layer thicknesses, case depth, surface hardness, fracture toughness estimate $\left(\mathrm{K}_{\mathrm{IC} 0}\right)$ and maximum residual stresses of the diffusion zone of plasma nitrided samples are given in Table 4. For nitriding temperatures up to $500{ }^{\circ} \mathrm{C}$, as temperature and time increase surface hardness also increases. The behavior seems to be, due to the increase of the compound layer thickness. For $550^{\circ} \mathrm{C}$ on the other hand, the surface hardness is lower than for $500{ }^{\circ} \mathrm{C}$, which happened due to the over tempering of the substrate, as core hardness decreased for this temperature. Concerning fracture toughness, samples have to be divided into 2 groups, the first presenting the direct appearance of concentric cracks (for 400 and $450^{\circ} \mathrm{C}$ ) and the second where first Palmqvist cracks were observed. For the first group, it is clear that a too thin compound layer is not able to protect the diffusion zone to be deformed, and this deformation reveals a fault of bearing load capacity starting to some load. For the second group a direct evaluation of the $\mathrm{K}_{\mathrm{IC} 0}$ was possible and revealed slightly higher values for $550{ }^{\circ} \mathrm{C}$ than for $500{ }^{\circ} \mathrm{C}$.

Although the residual stresses have been measured only in the diffusion zone and the cracks being located in the compound layer. It is known that the compound layer is normally in a tensile residual stress state ${ }^{30}$. It is also feasible to suppose that the more compressive the diffusion zone, the less tensile the compound layer and this could be an explanation for the slightly higher toughness values measured in the compound layer for $550^{\circ} \mathrm{C}$ than for $500^{\circ} \mathrm{C}$. 
Table 4. Compilation of results from compound layer thickness, case depth, surface hardness, fracture toughness estimate $\left(\mathrm{K}_{\mathrm{ICO}}\right)$ and maximum residual stresses of the diffusion zone.

\begin{tabular}{cccccc}
\hline Nitriding parameters & $\begin{array}{c}\text { Compound layer } \\
\text { thickness }(\mu \mathrm{m})\end{array}$ & $\begin{array}{c}\text { Case depth } \\
(\mu \mathrm{m})\end{array}$ & $\begin{array}{c}\text { Surface hardness } \\
\left(\mathrm{HV}_{0.1}\right)\end{array}$ & $\begin{array}{c}\mathrm{K}_{\mathrm{IC} 0} \text { estimate } \\
\left(\mathrm{MN} / \mathrm{m}^{3 / 2}\right)\end{array}$ & $\begin{array}{c}\text { Residual stresses } \\
(\mathrm{MPa})\end{array}$ \\
\hline $550^{\circ} \mathrm{C}-3 \mathrm{~h}$ & $7.9 \pm 0.3$ & $253.4 \pm 23.5$ & $1195.0 \pm 45.0$ & 5.92 & $-691.5 \pm 79.8$ \\
\hline $550^{\circ} \mathrm{C}-6 \mathrm{~h}$ & $9.6 \pm 0.3$ & $308.6 \pm 24.4$ & $1088.9 \pm 46.2$ & 14.94 & $-689.8 \pm 42.9$ \\
\hline $550^{\circ} \mathrm{C}-9 \mathrm{~h}$ & $11.5 \pm 0.2$ & $335.6 \pm 15.6$ & $1028.8 \pm 50.2$ & 7.67 & $-706.0 \pm 30.9$ \\
\hline $500^{\circ} \mathrm{C}-3 \mathrm{~h}$ & $4.3 \pm 0.2$ & $139.2 \pm 30.3$ & $1246.2 \pm 95.5$ & 5.62 & $-945.9 \pm 50.0$ \\
\hline $500^{\circ} \mathrm{C}-6 \mathrm{~h}$ & $6.7 \pm 0.3$ & $192.4 \pm 24.9$ & $1294.8 \pm 107.8$ & 5.87 & $-1047.0 \pm 16.5$ \\
\hline $500^{\circ} \mathrm{C}-9 \mathrm{~h}$ & $8.2 \pm 0.2$ & $245.4 \pm 40.3$ & $1079.2 \pm 86.7$ & 5.21 & $-885.2 \pm 8.1$ \\
\hline $450^{\circ} \mathrm{C}-3 \mathrm{~h}$ & $2.6 \pm 0.3$ & $97.6 \pm 20.5$ & $1253.5 \pm 55.9$ & - & $-1498.1 \pm 87.9$ \\
\hline $450^{\circ} \mathrm{C}-6 \mathrm{~h}$ & $3.9 \pm 0.2$ & $131.1 \pm 24.5$ & $1105.3 \pm 89.9$ & - & $-1297.2 \pm 66.7$ \\
\hline $450^{\circ} \mathrm{C}-9 \mathrm{~h}$ & $4.8 \pm 0.4$ & $169.3 \pm 40.4$ & $1101.5 \pm 56.2$ & - & $-1351.2 \pm 43.9$ \\
\hline $400^{\circ} \mathrm{C}-3 \mathrm{~h}$ & $0.6 \pm 0.2$ & $66.8 \pm 19.9$ & $1060.4 \pm 38.6$ & - & $-1688.3 \pm 62.4$ \\
\hline $400^{\circ} \mathrm{C}-6 \mathrm{~h}$ & $1.5 \pm 0.2$ & $98.5 \pm 11.7$ & $1050.9 \pm 28.2$ & - & $-1744.3 \pm 59.2$ \\
\hline $400^{\circ} \mathrm{C}-9 \mathrm{~h}$ & $2.7 \pm 0.3$ & $125.1 \pm 21.5$ & $1095.5 \pm 94.8$ & - & $-1628.4 \pm 47.9$ \\
\hline
\end{tabular}

\section{Conclusions}

- $\quad$ Plasma nitriding the DIN $18 \mathrm{MnCrSiMo6}-4$ continuous cooling bainitic steel using the gas composition with $76 \mathrm{vol} . \% \mathrm{~N}_{2}$ and $24 \mathrm{vol} . \% \mathrm{H}_{2}$ took to the formation of a compound layer formed by $\varepsilon-\mathrm{Fe}_{2-3}(\mathrm{C}) \mathrm{N}$ and $\gamma^{\prime}-\mathrm{Fe}_{4} \mathrm{~N}$ nitrides phase with a predominant presence of $\varepsilon-\mathrm{Fe}_{2-3}(\mathrm{C}) \mathrm{N}$. The thickness of the compound layer and diffusion zone increased with increasing treatment time and temperature. The nitriding layer depth presented a linearly dependence with the square root of the time. A proportionality constant has been determined for the different nitriding times;

- The maximum surface hardness was obtained at $500{ }^{\circ} \mathrm{C}$ for $6 \mathrm{~h}$, however the deepest layers were found for $550{ }^{\circ} \mathrm{C}$ for $9 \mathrm{~h}$;

- Nitriding with $500{ }^{\circ} \mathrm{C}$ of temperature gave the best results, since up to this value the core hardness was not impaired and the case depth increased significantly. The use of low treatment temperatures $\left(400\right.$ and $450{ }^{\circ} \mathrm{C}$ ) requires too long treatment times to achieve the expected case depth;

- Fracture toughness by Vickers indentation of the compound layer formed on DIN 18MnCrSiMo6-4 steel could be determined only for thicker layers, as for thin layers there is a lack of support and only peripheral circumferential cracks were observed. A linear relationship was obtained between fracture toughness of steel and case depth;

- As the result of nitride precipitation, the diffusion zone of the different plasma nitrided conditions presented compressive residual stresses. In general, higher nitriding temperatures and time leaded to deeper nitride layers with compressive residual stresses up to the end of the layers in core direction. On the other hand, the surface residual stresses increased as the nitriding temperature decreased. This means flatter residual stress gradients are present for higher nitriding temperatures. The time seems not have influencing the surface residual stresses so significantly;

- Plasma nitriding has shown good potential to improve the surface properties of the DIN 18MnCrSiMo6-4 continuous cooling bainitic steel. It leads to a significant increment of surface hardness within a relative thick compound layer and a deep diffusion zone where high compressive residual stresses are measured. Besides that, nitriding at temperatures of $500{ }^{\circ} \mathrm{C}$ and below preserved material's core hardness. Different gas compositions shall now be tested in the treatment for further improvement of the layer properties.

\section{Acknowledgments}

This work was carried out with the support of CAPES, a Brazilian government entity focused on human resources training, with the support of CAPES BRAGECRIM PROGRAM (Process no. 88881.142485/2017-01 - aid number 1844/2017) and CAPES - PROEX (Process 23038.000341/2019-71). A.S. Rocha acknowledges CNPq (Grant 308773/2018-7).

\section{References}

1. Rowe J. Advanced materials in automotive engineering. Cambridge: Woodhead Publishing; 2012. 340 p. http://dx.doi. org/10.1533/9780857095466.

2. Demeri MY. Advanced high-strength steels: science, technology, and applications. Materials Park: ASM International; 2013.301 p. http://dx.doi.org/10.31399/asm.tb.ahsssta.9781627082792.

3. Zhao J, Jiang Z. Thermomechanical processing of advanced high strength steels. Prog Mater Sci. 2018;94:174-242. http:// dx.doi.org/10.1016/j.pmatsci.2018.01.006.

4. Hasler S, Roelofs H, Lembke M, Caballero FG. New air cooled steels with outstanding impact toughness. In: Proceedings of the 3rd International Conference on Steels in Cars and Trucks; 2011; Salzburg. Salzburg, Austria: Stahleisen; 2011.

5. Keul C, Wirths V, Bleck W. New bainitic steel for forgings. Arch Civ Mech Eng. 2012;12(2):119-25. http://dx.doi.org/10.1016/j. acme.2012.04.012.

6. Raedt H, Speckenheuer U, Vollrath K. New forged steels: energy-efficient solutions for stronger parts. ATZ Autotechnology. 2012;12(1):12-7. http://dx.doi.org/10.1365/s35595-012-0089-9.

7. Buchmayr B. Critical assessment 22: bainitic forging steels. Mater Sci Technol. 2016;32(6):517-22. http://dx.doi.org/10.1 080/02670836.2015.1114272.

8. Merkel C, Engineer J. Hochfester bainitischer stahl 20MnCrMo7 für umformanwendungen. Schmiede Journal. 2014;38-41. 
9. Eggbauer G, Buchmayr B. High-strength bainitic steels for forged products. Berg Huttenmannische Monatshefte. 2015;160(5):20913. http://dx.doi.org/10.1007/s00501-015-0351-8.

10. Leskovsek V, Podgornik B, Nolan D. Modelling of residual stress profiles in plasma nitrided tool steel. Mater Charact. 2008;59(4):454-61. http://dx.doi.org/10.1016/j.matchar.2007.03.009.

11. Ochoa EA, Wisnivesky D, Minea T, Ganciu M, Tauziede C, Chapon $\mathrm{P}$, et al. Microstructure and properties of the compound layer obtained by pulsed plasma nitriding in steel gears. Surf Coat Tech. 2009;203(10-11):1457-61. http://dx.doi.org/10.1016/j. surfcoat.2008.11.025.

12. Podgornik B, Leskovsek V, Kovacic M, Vizintin J. Analysis and prediction of residual stresses in nitrided tool steel. Mater Sci Forum. 2011;681:352-7. http://dx.doi.org/10.4028/www. scientific.net/MSF.681.352.

13. Dong J, Epp J, Rocha AS, Nunes RM, Zoch H-W. Investigation of the influence factors on distortion in induction-hardened steel shafts manufactured from cold-drawn rod. Metall Mater Trans, A Phys Metall Mater Sci. 2016;47A(2):877-88. http:// dx.doi.org/10.1007/s11661-015-3250-4.

14. Abdalla AJ, Santos D, Vasconcelos G, Baggio-Scheid VH, Silva DF. Changing in fatigue life of $300 \mathrm{M}$ bainitic steel after laser carburizing and plasma nitriding. MATEC Web of Conferences. 2018;165:21002. http://dx.doi.org/10.1051/ matecconf/201816521002.

15. Li CX, Georges J, Li XY. Active screen plasma nitriding of austenitic stainless steel. Surf Eng. 2002;18(6):453-8. http:// dx.doi.org/10.1179/026708402225006240.

16. Sirin SY, Sirin K, Kaluc E. Effect of the ion nitriding surface hardening process on fatigue behavior of AISI 4340 steel. Mater Charact. 2008;59(4):351-8. http://dx.doi.org/10.1016/j. matchar.2007.01.019.

17. Sun Y, Bell T. Plasma surface engineering of low alloy steel. Mater Sci Eng A. 1991;140:419-34. http://dx.doi.org/10.1016/09215093(91)90458-Y.

18. Bhadeshia HKDH. Bainite in steels: theory and practice. 3rd ed. Cambridge: Maney Publisching; 2015. 589 p.

19. Zajac S, Komenda J, Morris P, Dierickx P, Matera S, Penalba Diaz F. Quantitative structure-property relationship for complex bainitic microstructures. Luxembourg: European Commission; 2005. 157 p. (Technical Steel Research Report; EUR 21245EN).

20. Caballero FG, Garcia-Mateo C, Cornide J, Allain S, Puerta J, Crouvizier M, et al. New advanced ultra high strength bainitic steels: ductility and formability (DUCTAFORM). Luxembourg: Research Fund for Coal and Steel, European Commission; 2013.

21. Roelofs H, Hasler S, Urlau U, Lembke MI, Olschewski G. Continuously cooled bainitic steel HSX®Z12: one decade of experience. In: Proceedings of the 4th International Conference on Steels in Cars and Trucks; 2014; Braunschweig, Germany. Germany: SCT; 2014.
22. ASTM: American Society for Testing and Materials. ASTM E18: standard test methods for Rockwell hardness of metallic materials. West Conshohocken: ASTM International; 2019.

23. ASTM: American Society for Testing and Materials. ASTM E92: standard test methods for Vickers hardness and Knoop hardness of metallic materials. West Conshohocken: ASTM International; 2017.

24. DIN: Deutsches Institut für Normung. DIN 50 190: härtetiefe wärmebehandelter tiele: ermittlung der nitrierhärtetiefe: teil 3. Berlin: DIN; 1979.

25. Nolan D, Leskovsek V, Jenko M. Estimation of fracture toughness of nitride compound layer on tool steel by application of the Vickers indentation method. Surf Coat Tech. 2006;201(12):182-8. http://dx.doi.org/10.1016/j.surfcoat.2005.11.077.

26. Shetty DK, Wright IG, Mincer PN, Clauer AH. Indentation fracture of WC-Co cermets. J Mater Sci. 1985;20(5):1873-82. http://dx.doi.org/10.1007/BF00555296.

27. Lampman S. Introduction to surface hardening of steels. In: ASM International. Metals handbook: heat treating. Utah: International Library Service; 1991. p. 259-267. (vol. 4).

28. Skonieski AFO, Santos GR, Hirsch TK, Rocha AS. Metallurgical response of an AISI 4140 steel to different plasma nitriding gas mixtures. Mater Res. 2013;16(4):884-90. http://dx.doi. org/10.1590/S1516-14392013005000073.

29. Gong W, Tomota Y, Harjo S, Su YH, Aizawa K. Effect of prior martensite on bainite transformation in nanobainite steel. Acta Mater. 2015;85:243-9. http://dx.doi.org/10.1016/j. actamat.2014.11.029.

30. Rocha AS, Strohaecker T, Tomala V, Hirsch T. Microstructure and residual stresses of a plasma-nitrided M2 tool steel. Surf Coat Tech. 1999;115(1):24-31. http://dx.doi.org/10.1016/ S0257-8972(99)00063-8.

31. Genel K, Demirkol M, Çapa M. Effect of ion nitriding on fatigue behavior of AISI 4140 steel. Mater Sci Eng A. 2000;279(12):207-16. http://dx.doi.org/10.1016/S0921-5093(99)00689-9.

32. Limodin N, Verreman Y. Fatigue strength improvement of a 4140 steel by gas nitriding: influence on notch severity. Mater Sci Eng A. 2006;435-436:460-7. http://dx.doi.org/10.1016/j. msea.2006.07.034.

33. Soleimani SMY, Mashreghi AR, Ghasemi SS, Moshrefifar M. The effect of plasma nitriding on the fatigue behavior of DIN 1.2210 cold work tool steel. Mater Des. 2012;35:87-92. http:// dx.doi.org/10.1016/j.matdes.2011.09.067.

34. Oettel H, Schreiber G. Formation of residual stresses in the diffusion layer: nitriren und nitrocarburieren. Wiesbaden: AWT Tagungsband; 1991. p. 139.

35. Alsaran A, Karakan M, Çelik A. The investigation of mechanical properties of ion-nitrided AISI 5140 low-alloy steel. Mater Charact. 2002;48(4):323-7. http://dx.doi.org/10.1016/S10445803(02)00275-9. 